\title{
The demographic, sexual health and behavioural correlates of Mycoplasma genitalium infection among women with clinically suspected pelvic inflammatory disease
}

\author{
V L Short, ${ }^{1}$ P A Totten, ${ }^{2}$ R B Ness, ${ }^{3}$ S G Astete, ${ }^{2}$ S F Kelsey, ${ }^{1}$ P Murray, \\ C L Haggerty ${ }^{1}$
}

${ }^{1}$ Department of Epidemiology, University of Pittsburgh, Pittsburgh, Pennsylvania, USA ${ }^{2}$ Department of Medicine, Division of Infectious Diseases, University of Washington, Seattle, Washington, USA ${ }^{3}$ The University of Texas School of Public Health, Houston, Texas, USA ${ }^{4}$ Children's Hospital of Pittsburgh of University of Pittsburgh Medical Center, Pittsburgh, Pennsylvania, USA

Correspondence to Dr V L Short, 130 DeSoto Street, 519 Parran Hall, Pittsburgh, PA 15232, USA;

c-vshort@state.pa.us

Accepted 10 August 2009 Published Online First 24 August 2009

\section{ABSTRACT}

Objective Mycoplasma genitalium has been identified as a cause of pelvic inflammatory disease (PID), a clinical syndrome associated with inflammation of the female upper genital tract and serious reproductive sequelae. As the demographic, behavioural and sexual risk profile of women with $M$ genitalium-associated PID is not well understood, the characteristics of $M$ genitalium-infected women presenting with clinically suspected PID were investigated.

Methods Data from 586 participants in the PID Evaluation and Clinical Health Study were analysed. Demographic, sexual history and behavioural characteristics, including age, race, marital status, education level, sexual activity, number of sexual partners, history of sexually transmitted infection (STI), bacterial vaginosis and PID, contraception use, oral and anal sex, age at sexual debut, douching practices and drug, alcohol and tobacco use, were compared between 88 women testing positive and 498 women testing negative for $M$ genitalium by PCR in the cervix and/or endometrium. Twenty-two women with $M$ genitalium mono-infections were compared with 172 women who tested positive for Neisseria gonorrhoeae by culture and/ or Chlamydia trachomatis by PCR.

Results Age under 25 years, douching two or more times per month and smoking were independently associated with $M$ genitalium. Women with $M$ genitalium mono-infections were significantly less likely to be African-American (59.1\% vs $86.0 \%, p=0.001$ ) than women with $N$ gonorrhoeae and/or $C$ trachomatis. Conclusions Women infected with $M$ genitalium had some characteristics commonly associated with PID and other STI. The demographic, sexual and behavioural characteristics of $M$ genitalium-positive women were similar to women with chlamydial and/or gonococcal PID.

Mycoplasma genitalium has recently been cited as a possible cause of pelvic inflammatory disease (PID) ${ }^{1}$ the inflammation of the female upper genital tract caused by the ascension of organisms from the lower genital tract. As serious sequelae, including tubal factor infertility and chronic pelvic pain frequently follow an episode of $\mathrm{PID}^{2}{ }^{2}$ it is important to identify correlates associated with PID-causing pathogens. As the risk factors associated with $M$ genitalium infection among women with PID have not been studied, we sought to describe the demographic, sexual health and behavioural correlates for $M$ genitalium in a popula- tion of women with clinically suspected PID. We hypothesise that the risk profile of $M$ genitalium will be similar to that for Chlamydia trachomatis and Neisseria gonorrhoeae.

\section{MATERIALS AND METHODS \\ Study population}

We analysed baseline data of the PID Evaluation and Clinical Health (PEACH) Study, described in detail elsewhere. ${ }^{3}$ Women were eligible to participate in the PEACH Study if they had clinically suspected PID, defined by: (1) acute pelvic pain $(<30$ days); (2) a clinical finding of pelvic tenderness; and (3) evidence of lower genital tract inflammation. For this ancillary study, stored cervical and endometrial specimens were available from a subset of 586 participants and were tested for $M$ genitalium. ${ }^{1}$ The demographic, behavioural and clinical characteristics of women with available specimens and those without did not differ significantly.

\section{Baseline data collection}

As part of the parent study, demographic, sexual history and behavioural characteristics were measured by questionnaire, and cervical swabs and endometrial biopsies were analysed for $N$ gonorrhoeae by culture and $C$ trachomatis by PCR (Roche Diagnostics, Indianapolis, Indiana, USA). ${ }^{3}$ For this subsequent study, these previously collected cervical and endometrial samples stored at $-70^{\circ} \mathrm{C}$ were tested for $M$ genitalium using PCR. ${ }^{14}$

\section{Statistical methods}

Associations between $M$ genitalium infection and correlates were assessed with univariate and multivariate logistic regression models, the latter which also included variables measuring $C$ trachomatis and/or $N$ gonorrhoeae infection. As results for lower and upper genital tract $M$ genitalium infection were similar, only results for combined cervical and/ or endometrial $M$ genitalium are presented. The $\chi^{2}$ test was used to compare the risk profile of women with $M$ genitalium mono-infection with women with $C$ trachomatis and/or $N$ gonorrhoeae.

\section{RESULTS}

Age under 25 years (odds ratio (OR) 2.3, 95\% CI 1.3 to 4.1 ), douching two or more times per month (OR $1.9,95 \%$ CI 1.2 to 3.3 ) and smoking (OR 1.9, 95\% CI 1.2 to 3.1$)$ were significantly associated with $M$ genitalium (table 1)

In a multivariate model adjusting for the above variables, age less than 25 years (adjusted odds ratio 
Table 1 Characteristics of study participants and association with $M$ genitalium cervical and/or endometrial infection

\begin{tabular}{|c|c|c|c|c|}
\hline Characteristic & $\begin{array}{l}\begin{array}{l}\text { M. genitalium } \\
\text { positive }\end{array} \\
\mathrm{N}=88 \\
\mathrm{n}(\%)^{*}\end{array}$ & $\begin{array}{l}\begin{array}{l}M . \text { genitalium } \\
\text { negative }\end{array} \\
\mathrm{N}=498 \\
\mathrm{n}(\%) \dagger\end{array}$ & OR (95\% Cl) & AOR $(95 \% \mathrm{Cl})$ \\
\hline \multicolumn{5}{|l|}{ Demographics } \\
\hline \multicolumn{5}{|l|}{ Age } \\
\hline$<25$ years & $71(18.2)$ & $319(81.8)$ & $2.3(1.3$ to 4.1$)$ & 2.7 (1.5 to 4.7$)$ \\
\hline$\geq 25$ years & $17(8.7)$ & 179 (91.3) & & \\
\hline \multicolumn{5}{|l|}{ Race/ethnicity } \\
\hline African-American & $69(16.2)$ & $358(83.8)$ & $1.4(0.8$ to 2.4$)$ & $-\ddagger$ \\
\hline White/Hispanic/other & $19(11.9)$ & $140(99.1)$ & & \\
\hline \multicolumn{5}{|l|}{ Marital status } \\
\hline Unmarried & $71(14.7)$ & $411(85.3)$ & $1.4(0.6$ to 3.1$)$ & $-\ddagger$ \\
\hline Married & $7(11.3)$ & $55(88.7)$ & & \\
\hline \multicolumn{5}{|l|}{ Education } \\
\hline$<$ High school & $38(16.7)$ & $189(83.3)$ & $1.2(0.8$ to 2.0$)$ & $-\ddagger$ \\
\hline$\geq$ High school & $50(13.9)$ & $308(86.0)$ & & \\
\hline \multicolumn{5}{|l|}{ Sexual health } \\
\hline \multicolumn{5}{|l|}{ Sexually active } \\
\hline Yes & $78(15.8)$ & $415(84.2)$ & $1.6(0.8$ to 3.1$)$ & $-\ddagger$ \\
\hline No & $10(10.7)$ & $83(89.2)$ & & \\
\hline \multicolumn{5}{|c|}{ Two or more life time sexual partners } \\
\hline Yes & $10(17.9)$ & $46(82.1)$ & $1.3(0.6$ to 2.6$)$ & $-\ddagger$ \\
\hline No & $78(14.7)$ & $452(85.3)$ & & \\
\hline \multicolumn{5}{|c|}{ New sexual partner in past month } \\
\hline Yes & $10(17.5)$ & $47(82.5)$ & $1.2(0.6$ to 2.5$)$ & $-\ddagger$ \\
\hline No & $78(14.7)$ & $451(85.3)$ & & \\
\hline \multicolumn{5}{|l|}{ History of STI§ } \\
\hline Yes & $52(15.0)$ & $295(85.0)$ & $1.0(0.6$ to 1.6$)$ & $-\ddagger$ \\
\hline No & $35(15.0)$ & $198(85.0)$ & & \\
\hline \multicolumn{5}{|c|}{ History of bacterial vaginosis } \\
\hline Yes & $13(10.0)$ & $117(90.0)$ & $0.6(0.3$ to 1.0$)$ & $-\ddagger$ \\
\hline No & $73(16.7)$ & $365(83.3)$ & & \\
\hline \multicolumn{5}{|l|}{ History of PID } \\
\hline Yes & $23(12.9)$ & $155(87.1)$ & $0.8(0.5$ to 1.3$)$ & $-\ddagger$ \\
\hline No & $64(15.9)$ & $338(84.1)$ & & \\
\hline \multicolumn{5}{|c|}{ Hormonal contraception use } \\
\hline Yes & $17(15.6)$ & $92(84.4)$ & $0.9(0.5$ to 1.8$)$ & $-\ddagger$ \\
\hline No & $61(15.9)$ & $323(84.1)$ & & \\
\hline \multicolumn{5}{|c|}{ Rare/occasional condom use } \\
\hline Yes & $60(17.2)$ & $289(82.8)$ & $1.4(0.8$ to 2.6$)$ & $-\ddagger$ \\
\hline No & $18(12.5)$ & $126(87.5)$ & & \\
\hline \multicolumn{5}{|l|}{ Consistent condom use ${ }^{* *}$} \\
\hline Yes & $7(10.9)$ & $57(89.1)$ & $1.2(0.5$ to 2.7$)$ & $-\ddagger$ \\
\hline No & $71(16.5)$ & $358(83.5)$ & & \\
\hline \multicolumn{5}{|l|}{ Oral sex } \\
\hline Yes & $23(17.6)$ & $108(82.4)$ & $1.2(0.7$ to 2.0$)$ & $-\ddagger$ \\
\hline No & $63(15.0)$ & $356(85.0)$ & & \\
\hline \multicolumn{5}{|l|}{ Anal sex } \\
\hline Yes & $4(21.1)$ & $15(78.9)$ & $1.5(0.5$ to 4.7$)$ & $-\ddagger$ \\
\hline No & $84(14.8)$ & $483(85.2)$ & & \\
\hline Age at sexual debut & & & & \\
\hline$\leq 15$ years & $48(15.8)$ & $255(84.2)$ & $1.1(0.7$ to 1.8$)$ & $-\ddagger$ \\
\hline$>15$ years & $40(14.1)$ & $243(85.9)$ & & \\
\hline Behavioural & & & & \\
\hline $\begin{array}{l}\text { Vaginal douche two or } \mathrm{m} \\
\text { month }\end{array}$ & & & & \\
\hline Yes & $26(22.8)$ & $88(77.8)$ & $1.9(1.2$ to 3.3$)$ & $2.0(1.2$ to 3.4$)$ \\
\hline No & $62(13.1)$ & $410(86.9)$ & & \\
\hline Illicit drug use & & & & \\
\hline Yes & $32(20.4)$ & $125(79.6)$ & 1.7 (1.0 to 2.7$)$ & $-\ddagger$ \\
\hline No & $56(13.1)$ & $370(86.9)$ & & \\
\hline Current smoker & & & & \\
\hline Yes & $49(20.2)$ & $194(79.8)$ & $1.9(1.2$ to 3.1$)$ & $2.0(1.3$ to 3.3$)$ \\
\hline
\end{tabular}


Table 1 Continued

\begin{tabular}{|c|c|c|c|c|}
\hline \multirow[b]{3}{*}{ Characteristic } & \multirow{3}{*}{$\begin{array}{l}\begin{array}{l}M . \text { genitalium } \\
\text { positive }\end{array} \\
\mathrm{N}=88 \\
\mathrm{n}(\%)^{*}\end{array}$} & \multirow{3}{*}{$\begin{array}{l}\begin{array}{l}\text { M. genitalium } \\
\text { negative }\end{array} \\
\mathrm{N}=498 \\
\mathrm{n}(\%) \dagger \\
\end{array}$} & \multirow[b]{3}{*}{ OR (95\% CI) } & \multirow[b]{3}{*}{ AOR $(95 \% \mathrm{CI})$} \\
\hline & & & & \\
\hline & & & & \\
\hline No & $39(11.5)$ & 301 (88.5) & & \\
\hline \multicolumn{5}{|l|}{ Alcohol use } \\
\hline Yes & 48 (14.8) & $277(85.2)$ & $0.9(0.6$ to 1.5$)$ & $-\ddagger$ \\
\hline No & $40(15.5)$ & $218(84.5)$ & & \\
\hline \multicolumn{5}{|c|}{ Alcohol drinks per week } \\
\hline$>7$ drinks & $13(19.1)$ & $55(80.9)$ & $1.4(0.7$ to 2.7$)$ & $-\ddagger$ \\
\hline$\leq 7$ drinks & $75(14.6)$ & $440(85.4)$ & & \\
\hline \multicolumn{5}{|c|}{$\begin{array}{l}\text { Missing observations: marital status, } \mathrm{n}=42 ; \text { education, } \mathrm{n}=1 \text {; history of sexually transmitted in } \\
\mathrm{n}=18 ; \text { history of pelvic inflammatory disease (PID), } \mathrm{n}=6 ; \text { hormonal contraception use, } \mathrm{n}=93 ; \mathrm{co} \\
\text { smoking, } \mathrm{n}=3 \text {, alcohol use, } \mathrm{n}=3 \text {. } \\
\text { *Percentage of total study population with characteristic that tested positive for } M \text { genitalium. } \\
\text { †Percentage of total study population with characteristic that tested negative for } M \text { genitalium. } \\
\text { †Variables with a p value greater than } 0.10 \text { were not included in the multivariate analysis. } \\
\text { SHistory of } N \text { gonorrhoeae, } C \text { trachomatis, or Trichonomas vaginalis. } \\
\text { \Condoms used } 0 \text { to } 5 \text { out of } 10 \text { sexual encounters. } \\
{ }^{* *} \text { Condoms used } 10 \text { out of } 10 \text { sexual encounters. AOR, adjusted odds ratio; } 0 \mathrm{R} \text {, odds ratio. }\end{array}$} \\
\hline
\end{tabular}

(AOR) 2.7, 95\% CI 1.5 to 4.7 ), douching (AOR 2.0, 95\% CI 1.2 to 3.4) and smoking (AOR 2.0, 95\% CI 1.3 to 3.3) were independently associated with $M$ genitalium. After further adjusting for $C$ trachomatis and/or $N$ gonorrhoeae infection, age (AOR 3.0, 95\% CI 1.4 to 6.2 ) and smoking (AOR 1.9, 95\% CI 1.1 to 3.3) remained significantly associated with $M$ genitalium.

Women with $M$ genitalium mono-infection $(\mathrm{n}=22)$ were generally similar to women with $C$ trachomatis and/or $N$ gonorrhoeae $(\mathrm{n}=172)$ (results not shown). The only characteristic that differed between these two groups was race. Women with $M$ genitalium mono-infection were significantly less likely to be African-American $(59.1 \%$ vs $86.0 \%, \mathrm{p}=0.001)$ than women with $C$ trachomatis and/or $N$ gonorrhoeae.

\section{DISCUSSION}

Among women with clinically suspected PID, compared with women who tested negative, women positive for $M$ genitalium in the cervix and/or endometrium were more likely to have some characteristics and behaviours that are commonly associated with other sexually transmitted infections (STI) and PID, including young age, smoking and douching. Furthermore, the characteristics of $M$ genitalium were similar to those of $N$ gonorrhoeae and $C$ trachomatis. However, $M$ genitalium infection was not associated with all traditional markers of STI, including sexual activity, number of sexual partners, new sexual partner, history of STI or PID, condom use, oral and anal sex and age at sexual debut. Our findings are not consistent with other studies that have examined the risk factors for $M$ genitalium lower genital tract infection. ${ }^{5-7}$ However, all women enrolled in our study had clinically suspected PID. Therefore, they may have had a homogeneity of sexual risk behaviours, which probably biased these variables towards the null.

As patients infected with $M$ genitalium may have mild symptoms, ${ }^{578}$ an understanding of risk factors may aid efforts to reduce the acquisition, spread and complications of infection. As clinicians may use certain risk factors to decide who to screen for STI, including $N$ gonorrhoeae and $C$ trachomatis, and the risk factors for these pathogens and $M$ genitalium are largely the same, these same women should also be screened for $M$ genitalium. Such screening efforts could help detect and treat uncomplicated lower genital tract $M$ genitalium infections, which could ultimately prevent some PID cases.
Acknowledgements The authors would like to thank and acknowledge the efforts of interviewers who recruited and interviewed study participants: Susan Allen, Audrey Baum, Corina Becker, Hope Cohen-Webb, Amy Cooper, Peg Crowner, Leslie Curll, Jackie Faas, Amanda Farmer, Emily Hoffman, Anne Holdredge, Alice Howell, Susan Kay, Faye Leboeuf, Ingrid Macio, Kathy Martin, Margaret McNamee, Ann Meers, Kim Miller, Andrea Montagno, Joy Mowery, Jan Mitton, Cheryl Myers, Brenda Nobels, Tara Pealer, Anne Rideout, Georgia Rothstein, Carol Sams, Tara Schuda, Buffie Schiavoni, Marsha Scott, Kelly Timbers, Sam Whitaker, Lisa Williams and Mirza Vincetic. The authors also gratefully acknowledge consultants Tom Songer, $\mathrm{PhD}$, Judy Lave, PhD, and Sheryl Kelsey, PhD and technical assistant Debra Bass. Investigators involved in the PEACH Study include: Antonio Amortegui, MD; Susan L Hendrix, D0; Sharon L Hillier, PhD; Robert L Holley, MD; Deborah B Nelson, PhD; John Nichols, Jr, MD; Jeffrey Peipert, MD; Hugh Randall, MD; Diane Schubeck, MD; Steven J Sondheimer, MD; David E Soper, MD; Richard L Sweet, MD; Wayne Trout, MD; Guiliana Trucco, MD; Harold C Wiesenfeld, MD and Tamer Yalcinkaya, MD.

Funding This study received funding through grant HS08358-05 from the Agency for Healthcare Research and Quality Development and 1 R01 Al067661-01A2 from the National Institute of Allergy and Infectious Diseases.

Contributors VLS analysed the data and wrote the final draft; CLH conceived the paper and edited the manuscript; PAT, RBN, SFK and PM edited the manuscript; SGA and PAT assisted with laboratory analyses.

\section{Competing interests None.}

Ethics approval Ethics approval was obtained from the University of Pittsburgh.

Provenance and peer review Not commissioned; externally peer reviewed.

\section{REFERENCES}

1. Haggerty CL, Totten PA, Astete SG, et al. Failure of cefoxitin and doxycycline to eradicate endometrial Mycoplasma genitalium and the consequence for clinical cure of pelvic inflammatory disease. Sex Transm Infect 2008;84:338-42.

2. Westrom L. Effect of acute pelvic inflammatory disease on fertility. Am J Obstet Gynecol 1975;121:707-13.

3. Ness RB, Soper DE, Peipert J, et al. Design of the PID Evaluation and Clinical Health (PEACH) Study. Control Clin Trials 1998:19:499-514.

4. Dutro SM, Hebb JK, Garin CA, et al. Development and performance of a microwellplate-based polymerase chain reaction assay for Mycoplasma genitalium. Sex Transm Dis 2003;30:756-63.

5. Huppert JS, Mortensen JE, Reed JL, et al. Mycoplasma genitalium detected by transcription-mediated amplification is associated with Chlamydia trachomatis in adolescent women. Sex Transm Dis 2008;35:250-4.

6. Manhart LE, Holmes KK, Hughes JP, et al. Mycoplasma genitalium among young adults in the United States: an emerging sexually transmitted infection. Am J Public Health 2007;97:1118-25.

7. Tosh AK, Van Der Pol B, Fortenberry JD, et al. Mycoplasma genitalium among adolescent women and their partners. J Adolesc Health 2007;40:412-17.

8. Short VL, Totten PA, Ness RB, et al. Clinical presentation of Mycoplasma genitalium infection versus Neisseria gonorrhoeae infection among women with pelvic inflammatory disease. Clin Infect Dis 2009;48:41-7. 